Brit. J. Ophthal. (1959) 43, 102.

\title{
STANDARDIZED X-TONOMETERS*
}

BY

\author{
C. R. S. JACKSON† \\ Edinburgh
}

STANDARDIZED Schiötz tonometers of the original (weighted) type have been on sale in the United States for more than 10 years, and a considerable amount of information has been collected which bears out the acceptability of the current specification. This knowledge was assembled in the First Decennial Report of the Committee on Standardization of Tonometers (1954).

Following the American lead, standardized tonometers have been introduced into the United Kingdom, and the work of the W. H. Ross Foundation (Scotland) in this field has already been described (Jackson, 1953, 1955).

The specification for the weighted model of the Schiötz tonometer is now internationally accepted, as is the new conversion of scale readings into mm. Hg (Schiötz) intra-ocular pressure. The instrument manufacturers, both in the U.K. and U.S.A., now submit their products to independent testing stations for examination and, if satisfactory, for certification as standard tonometers. These measures have at least introduced a considerable degree of uniformity between different tonometers, but it still has to be remembered that this type of tonometer is not without its own sources of instrumental error, which have been assessed by Friedenwald (1937), and that we must add to these the variables introduced by different observers, by the degree of relaxation of the patient, and his position, and by the time of day. I believe that the tendency to read a Schiötz tonometer to a degree of accuracy closer than the whole scale division is a mistaken one, and that the current calibration charts, which suggest a value for the various scale readings accurate to fractions of a millimetre of mercury, imply a standard of accuracy which is entirely misleading.

Some years after the introduction of his original tonometer, Schiötz (1927) described his tonometer with a convex plunger. This is what we know as the $\mathrm{X}$-tonometer, and is without the additional weights which were used in the original model to adjust the instrument to cover the various ranges of intra-ocular pressure. The different shape of the plunger-end enables a wide range of intra-ocular pressures to be registered without the need to alter the weight acting on the plunger. In the United States, the X-tonometer attracts very little interest. In the United Kingdom and in Scandinavia, on the other hand, the weightless model is very popular, and its sales greatly outnumber those of the weighted model.

From a study of Schiötz's original description of the weightless tonometer, together with the work of the American Committee, a specification has been

* Received for publication April 21, 1958.

+ In receipt of a grant from the W. H. Ross Foundation (Scotland) for the Study of the Prevention of Blindness. 102 
drawn up for the X-tonometer. This is given in detail at the end of this paper. Table I shows the ways in which the X-tonometer differs from the weighted model.

TABLE I

SPECIFICATION

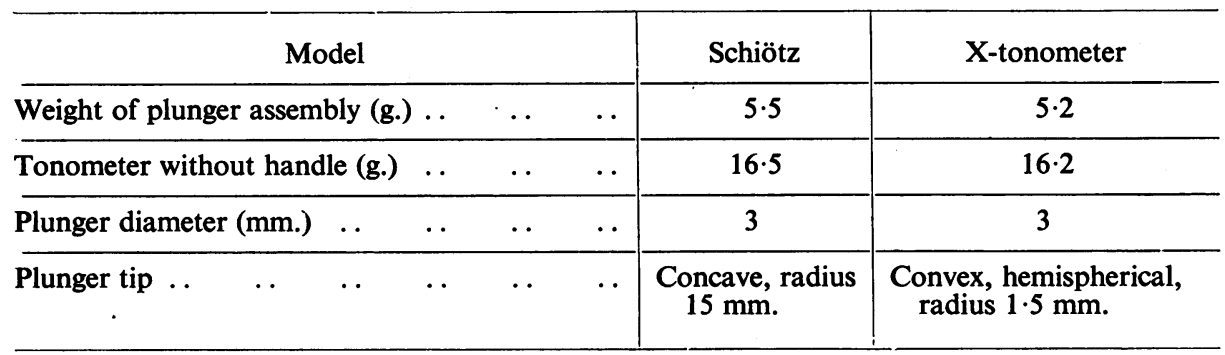

The zero for the X-tonometer to be set when plunger tip is $0.05 \mathrm{~mm}$. below footplate.

Apart from the calibration chart, which is discussed later, the instruments differ only in the shape of the end of the plunger and in the weight acting on the foot of the plunger when the tonometer is assembled. For manufacturing purposes, it is obviously desirable to have as many parts of the instruments as possible interchangeable, in order that the makers can easily turn to weighted or weightless tonometers, depending on the needs of their manufacturing programme.

The Americans having introduced a standard weighted tonometer, it was desirable that the new $\mathrm{X}$-tonometer should, if possible, give readings which were comparable with those of the weighted model. The whole problem of standardizing tonometers having come to a head, partly on account of the increasing speed and ease of travel, it is not difficult to imagine occasions on which tonometers of the two different types may be used to record the pressure in the same eye.

I have previously discussed (Jackson, 1955) the available methods of calibrating tonometers, and I decided to compare the prototype standard $\mathrm{X}$-tonometer with an accepted Schiötz tonometer on a series of human eyes. The standard reference model was made in America; it had been accepted by the American testing station, and it was examined at the tonometer testing station in Edinburgh to ensure that it remained in adjustment.

Both normal and pathological eyes were used in the trial. The normal eyes were those in which no suspicion of ocular disease was present; they had been anaesthetized in the out-patient department, usually for the removal of a chalazion, or for the syringing of the tear passages. The pathological eyes were mostly those of our glaucoma patients.

Three readings were made on each eye: with the Schiötz 5.5 and $7.5 \mathrm{~g}$. loads, and with the X-tonometer. The order in which the instruments were applied to the eye was varied in a random way; though it has been shown that the effect (on the intra-ocular pressure) of a short application of a tonometer is negligible. 
The distribution of the scale readings on the 405 normal eyes is shown in Fig. 1. The shape of the curve is similar in each instance, though the peak of the curve lies at a different point of the scale in each case. Calculation shows that the average reading was at 4.5 Scale Divisions for the Schiötz $5.5 \mathrm{~g}$. load, at 7.1 Scale Divisions for the $7.5 \mathrm{~g}$. load, and at 10.6 Scale Divisions for the $\mathrm{X}$-tonometer.

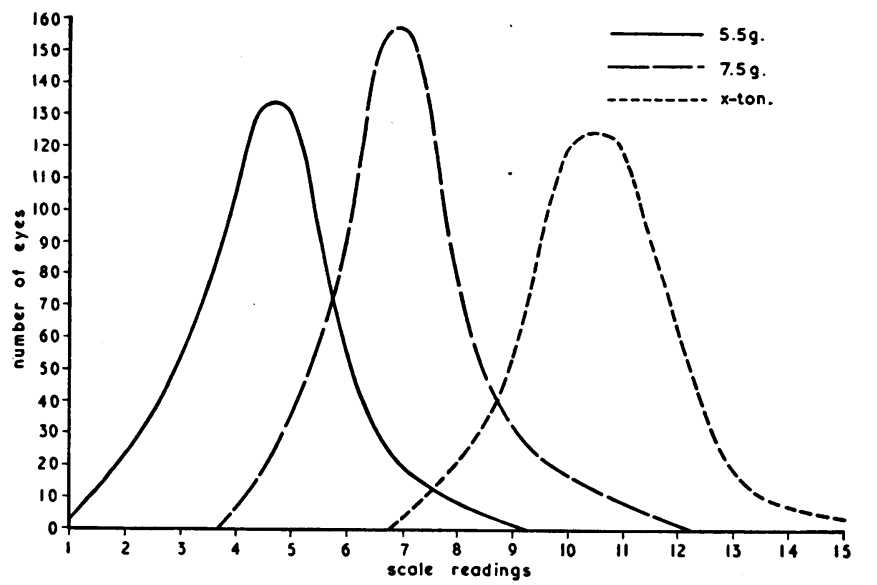

Fig. 1.-Distribution of original scale readings on 405 normal eyes. Schiötz 5.5 and $7.5 \mathrm{~g}$., and $\mathrm{X}$-ton-

Fig. 2 shows the result of moving the curves for the Schiötz $7.5 \mathrm{~g}$. and the $\mathrm{X}$-tonometer toward the curve for the Schiötz $5.5 \mathrm{~g}$. load by an amount depending on the differences between these mean readings. There is close correlation between the curves.

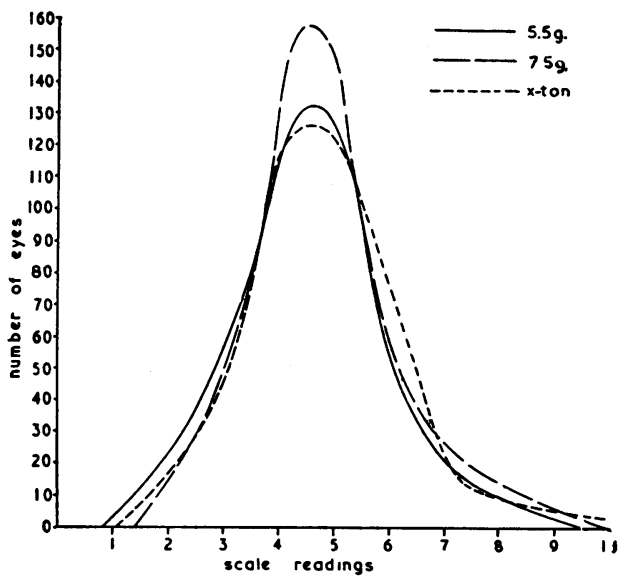

Fig. 2.-Distribution of scale readings revised by shifting the scale taking Schiötz $5.5 \mathrm{~g}$. as base.

The all-over pattern being satisfactory, it was necessary to determine how close would be the correlation if individual readings were adjusted in this way, in order to arrive at a basis for calibrating a standard X-tonometer. Each reading, in both the "normal" and "pathological" series, was therefore modified by a factor depending on the differences of the means, and the 
results were compared with the reading which would theoretically have been expected.

The comparisons are shown in Table II, which indicates that 90 per cent. of the corrected readings fall within \pm 1 Scale Division of the expected reading. Taking into account the difficulties of reading tonometers of the Schiötz type to greater limits of accuracy than one scale division, it is considered that no improvement on this form of cross-calibration is likely.

TABLE II EFFECT OF CORRECTION FACTORS

\begin{tabular}{|c|c|c|c|}
\hline \multicolumn{2}{|c|}{ Related to $5 \cdot 5 \mathrm{~g}$. Schiötz } & $\begin{array}{l}\text { Normal } \\
\text { (per cent.) }\end{array}$ & $\begin{array}{l}\text { Pathological } \\
\text { (per cent.) }\end{array}$ \\
\hline Corrected $7 \cdot 5 \mathrm{~g}$. & $\begin{array}{l} \pm 0.5 \\
\pm 1.5\end{array}$ & $\begin{array}{l}83 \cdot 9 \\
99 \cdot 2\end{array}$ & $\begin{array}{l}82 \cdot 1 \\
96 \cdot 6\end{array}$ \\
\hline Corrected X-tonometer & $\begin{array}{l} \pm 0 \\
\pm 1\end{array}$ & $\begin{array}{l}40 \cdot 9 \\
89 \cdot 3 \\
\end{array}$ & $\begin{array}{l}49 \cdot 6 \\
89 \cdot 5 \\
\end{array}$ \\
\hline \multicolumn{2}{|c|}{ Related to $7 \cdot 5 \mathrm{~g}$. Schiötz } & $\begin{array}{l}\text { Normal } \\
\text { (per cent.) }\end{array}$ & $\begin{array}{l}\text { Pathological } \\
\text { (per cent) }\end{array}$ \\
\hline Corrected X-tonometer & $\begin{array}{r} \pm 0.5 \\
- \pm 1.5\end{array}$ & $\begin{array}{l}73 \\
95\end{array}$ & $\begin{array}{l}74 \cdot 9 \\
94 \cdot 5\end{array}$ \\
\hline
\end{tabular}

A conversion chart which allows conversion of scale readings into $\mathrm{mm} . \mathrm{Hg}$ intra-ocular pressure according to the most recent conversion chart for the weighted tonometer is given in Fig. 3.

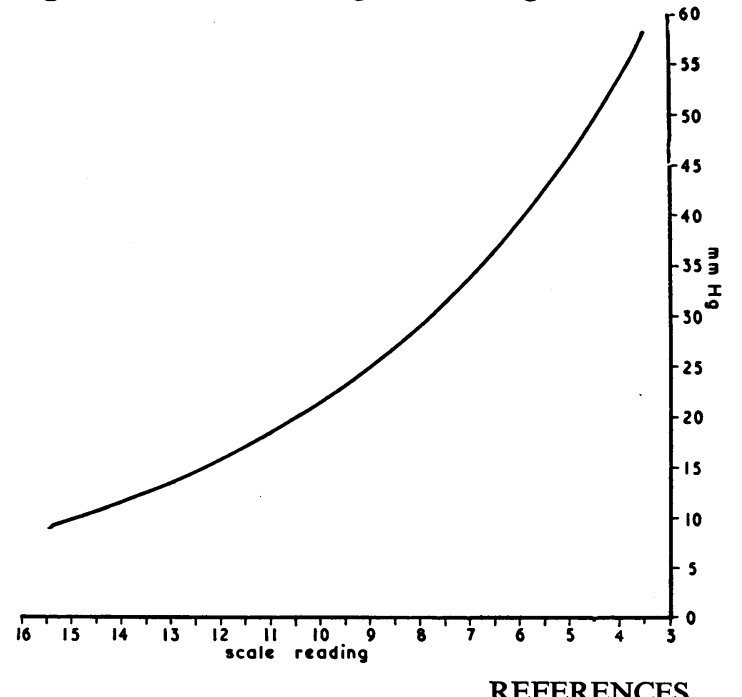

FIg. 3.-Proposed calibration chart for X-tonometer.

The figures are reproduced by kind permission of the Honorary Editors of the Proceedings of the Royal Society of Medicine.

Friedenwald, J. S. (1937). Amer. J. Ophthal., 20, 985.

, Chairman (1954). "Standardization of Tonometers". Decennial Report by the Committee on Standardization of Tonometers. American Academy of Ophthalmology and Otolaryngology. 
JACKSON, C. R. S. (1953). Brit. J. Ophthal., 37, 694.

(1955). Ibid., 39, 368.

(1957). Proc. roy. Soc. Med., 50, 674.

Sснї̈т, H. (1927). Brit. J. Ophthal., 11, 116.

APPENDIX

Provisional Specification of Standard X-Tonometer

All tonometers and plungers to carry serial numbers

\begin{tabular}{|c|c|c|c|c|c|c|c|}
\hline \multirow{2}{*}{ No. } & \multirow{2}{*}{\multicolumn{5}{|c|}{ Test }} & \multicolumn{2}{|c|}{ Specification } \\
\hline & & & & & & Standard & Limits \\
\hline 1 & $\begin{array}{r}\text { Weight (g.): (a) Plunger, l } \\
(b) \text { Tonomete }\end{array}$ & $\begin{array}{l}\text { ever, and po } \\
\text { er without ha }\end{array}$ & $\begin{array}{l}\text { ter, } S \\
\text { dle }\end{array}$ & $\begin{array}{l}\text { ale } 0 \\
\ldots\end{array}$ & $\begin{array}{l}\cdots \\
\cdots\end{array}$ & $\begin{array}{r}5 \cdot 2 \\
16 \cdot 2\end{array}$ & $\begin{array}{l} \pm 0 \cdot 15 \\
\pm 0 \cdot 25\end{array}$ \\
\hline 2 & Friction between Plunger & and Sleeve & . & . & . & \multicolumn{2}{|c|}{ Negligible } \\
\hline 3 & Friction between Handle & and Sleeve & . & . & . & \multicolumn{2}{|c|}{ Negligible } \\
\hline 4 & $\begin{array}{r}\text { Footplate Diameter }(\mathrm{mm} \text {.) } \\
\text { Curvature }(\mathrm{mm} \\
\text { Diameter of cur }\end{array}$ & $\begin{array}{l}\cdots \\
\text { rved surface }\end{array}$ & $\begin{array}{l}\because \\
\text { nin.) }\end{array}$ & $\begin{array}{l}\cdots \\
\cdots \\
\cdots\end{array}$ & $\begin{array}{l}\cdots \\
\cdots \\
\cdots\end{array}$ & $\begin{array}{r}10 \cdot 1 \\
15 \cdot 0 \\
9 \cdot 0\end{array}$ & $\begin{array}{l} \pm 0 \cdot 2 \\
\pm 0 \cdot 25\end{array}$ \\
\hline 5 & $\begin{array}{l}\text { Plunger Diameter (mm.) } \\
\text { Tip. Convex radiu }\end{array}$ & us (mm.) & $\begin{array}{l}\cdots \\
\cdots\end{array}$ & $\begin{array}{l}\cdots \\
\cdots\end{array}$ & $\begin{array}{l}\cdots \\
\cdots\end{array}$ & $\begin{array}{l}3 \cdot 0 \\
1 \cdot 5\end{array}$ & \pm 0.03 \\
\hline 6 & $\begin{array}{r}\text { Scale Indication On } 15 \mathrm{mr} \\
\text { On } 16 \mathrm{~m} \\
\text { On own }\end{array}$ & $\begin{array}{l}\text { m. standard } \\
\text { m. standard } \\
\text { block } \quad \cdots\end{array}$ & $\begin{array}{l}\cdots \\
\cdots \\
\cdots\end{array}$ & $\begin{array}{l}\cdots \\
\cdots \\
\cdots\end{array}$ & $\begin{array}{l}\cdots \\
\cdots \\
\cdots\end{array}$ & $\begin{array}{c}\text { (Tonometer } \\
\text { Scale) } \\
-1 \\
0 \\
0\end{array}$ & $\begin{array}{l} \pm 0 \cdot 2 \\
\pm 0 \cdot 2 \\
\pm 0 \cdot 2\end{array}$ \\
\hline 7 & 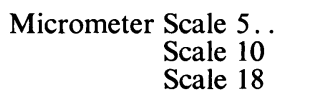 & $\begin{array}{ll}\cdots & \cdots \\
\cdots & \cdots \\
\cdots & \cdots\end{array}$ & $\begin{array}{l}\cdots \\
\cdots \\
\cdots\end{array}$ & $\begin{array}{l}\cdots \\
\cdots \\
\cdots\end{array}$ & $\begin{array}{l}\cdots \\
\cdots \\
\cdots\end{array}$ & $\begin{array}{r}5 \cdot 0 \\
10 \cdot 0 \\
18 \cdot 0\end{array}$ & $\begin{array}{l} \pm 0 \cdot 25 \\
\pm 0 \cdot 25 \\
\pm 1 \cdot 0\end{array}$ \\
\hline 8 & $\begin{array}{c}\text { Wobble (mm.) Plunger } \\
\text { Fulcrum }\end{array}$ & $\begin{array}{ll}\ldots & \ldots \\
\ldots & \ldots\end{array}$ & $\begin{array}{l}\cdots \\
\cdots\end{array}$ & $\begin{array}{l}\cdots \\
\cdots\end{array}$ & $\begin{array}{l}\cdots \\
\ldots\end{array}$ & $\begin{array}{l}0 \\
0\end{array}$ & $\begin{array}{l}0.4 \max . \\
0.4 \max .\end{array}$ \\
\hline 9 & Extension of Plunger belo & w Footplate & mm.) & . & . & - & 3.0 max. \\
\hline 10 & $\begin{array}{l}\text { Pointer Depth (mm.) } \\
\text { Thickness (mm.) }\end{array}$ & $\begin{array}{ll}. & \ldots \\
\ldots & \ldots\end{array}$ & $\begin{array}{l}\cdots \\
\cdots\end{array}$ & $\begin{array}{l}\cdots \\
\cdots\end{array}$ & $\begin{array}{l}\ldots \\
\cdots\end{array}$ & - & $\begin{array}{l}3.0 \max . \\
0.25 \max .\end{array}$ \\
\hline & Distance between Scale ar & nd Pointer ( $\mathrm{n}$ & m.) & .. & . & - & 1.0 max. \\
\hline 11 & \multicolumn{7}{|c|}{ Plunger contact with Hammer. Perpendicular 5-10 scale } \\
\hline 12 & \multicolumn{7}{|c|}{ Hammer, underside smooth, free from pits } \\
\hline 13 & \multicolumn{7}{|c|}{ Tonometer to have generally good construction } \\
\hline 14 & \multicolumn{7}{|c|}{$\begin{array}{l}\text { Test block to have a polished surface, } 16 \mathrm{~mm} . \pm .04 \text { spherical curvature, } \pm .14 \mathrm{~mm} \text {. } \\
\text { deviation from sphericity, over an area of } 11 \mathrm{~mm} \text {. minimum diameter }\end{array}$} \\
\hline 15 & \multicolumn{7}{|c|}{$\begin{array}{l}\text { Tonometer case to be dust-free and to contain a place for the plunger so that the instrument } \\
\text { can be taken apart for packaging }\end{array}$} \\
\hline 16 & \multicolumn{7}{|l|}{ Schiötz Chart Correct } \\
\hline
\end{tabular}

